\title{
EHMTI-0171. Headache disorders - current care of physiotherapy?
}

\author{
A Eder*, EJ Hurkmans, C Reindl, L Egretzberger, CH Edthofer \\ From 4th European Headache and Migraine Trust International Congress: EHMTIC 2014 \\ Copenhagen, Denmark. 18-21 September 2014
}

\section{Introduction}

Headache disorders are a major health problem in Europe and lead to widespread suffering and considerable economic consequences. For the treatment of these patients the World Health Organisation recommends the use of management guidelines. In some guidelines beside the treatment with medication other therapies like physiotherapy are also mentioned to be a potential treatment option.

\section{Aims}

So far, it remains unclear, to what extent physiotherapists are nowadays confronted with patients with headache disorders and which physiotherapy interventions are actually applied in this patient population.

\section{Methods}

A cross-sectional study by means of a digital questionnaire was send in January 2013 to 4892 members of Physio Austria (the professional organisation for physiotherapists in Austria). After two weeks a reminder was send.

\section{Results}

The questionnaire was returned by 627 physiotherapists, resulting in a response rate of $13 \% .70,1 \%$ of this physiotherapists treats in their clinical setting headache patients., either as primary diagnose $(70 \%)$ or as coexisting symptoms. Interventions like Manual therapy, Relaxation Training or Trigger Point therapy are applied according to clinical findings and anamneses.

\section{Conclusion}

The findings of this study show that physiotherapists are confronted with patients with headache disorders on a regular basis. Therefore it can be recommended that management of headache patients should be included in

University of Applied Sciences, FH Campus Wien, Vienna, Austria physiotherapy education and interdisciplinary teams could consider taking physiotherapists on board. Furthermore, scientific studies should focus in effectivity of physiotherapy interventions.

No conflict of interest.

Published: 18 September 2014
Submit your manuscript to a SpringerOpen ${ }^{\odot}$ journal and benefit from:

- Convenient online submission

- Rigorous peer review

- Immediate publication on acceptance

- Open access: articles freely available online

- High visibility within the field

- Retaining the copyright to your article

\section{SpringerOpen ${ }^{\circ}$}

(C) 2014 Eder et al; licensee Springer. This is an Open Access article distributed under the terms of the Creative Commons Attribution License (http://creativecommons.org/licenses/by/2.0), which permits unrestricted use, distribution, and reproduction in any medium, provided the original work is properly cited. 